УДК 330.341.1:332.1+339.92

Цеханович Виктор, аспірант кафедри економічної теорії, маркетингу та підприємництва, Д3 Луганський національний університет ім. Т. Шевченка, м. Старобільск, ORCID ID: 0000-0001-7199-8558 e-mail victor134@ukr.net

https://doi.org/10.29038/2786-4618-2021-02-34-41

\title{
ЄВРОРЕГІОНИ: ХАРАКТЕРИСТИКА ТА ПРИНЦИПИ ФУНКЦІОНУВАННЯ
}

У статті досліджуються принципи функціонування та характеристика єврорегіонів. Форми реалізації транскордонного співробітництва можуть варіюватись від встановлення та розвитку взаємовигідних контактів між різними суб'єктами та укладення угод про транскордонне співробітництво в окремих сферах до створення міжнародних територіальних утворень. Міжнародні територіальні утворення, до яких на основі укладених угод входять прикордонні адміністративні одиниці сусідніх держав, отримали назву єврорегіонів. Єврорегіоннайвища форма транскордонного співробітництва, а їхні структури є найбільш комплексною і ефективною формою утворень, в рамках яких формуються і діють різноманітні коопераційні, координаційні та корпоративні механізми. Розробки і втілення принципово нових підходів до розвитку єврорегіонів в України в умовах розширення ЄС вимагають радикальні зрушення у геополітичній ситуації на європейському континенті та зміна геополітичного статусу єврорегіонів після масштабного розширення європейської спільноти.

Ключові слова: єврорегіони, єврорегіональне співробітництво, транскордонне співробітництво, фактори

\section{Цеханович Виктор,} аспирант кафедры экономической теории, маркетинга и предпринимательства, ГУ Луганский национальный университет им.Т. Шевченко,

г. Старобельск,

\section{ЕВРОРЕГИОНЫ: ХАРАКТЕРИСТИКАТА ПРИНЦИПЫ ФУНКЦИОНИРОВАНИЯ}

В статье исследуются принципы функционирования и характеристика еврорегионов. Формы реализации трансграничного сотрудничества могут варьироваться от установления и развития взаимовыгодных контактов между различными субъектами и заключения соглашений о трансграничном сотрудничестве в отдельных сферах до создания международных территориальных образований. Международные территориальные образования, в которые на основе заключенных соглашений входят пограничные административные единицы соседних государств, получили название еврорегионов. Еврорегион-высшая форма трансграничного сотрудничества, а их структуры является наиболее комплексной и эффективной формой образований, в рамках которых формируются и действуют различные кооперационные, координационные и корпоративные механизмы. Разработки и внедрения принципиально новых подходов к развитию еврорегионов в условиях расширения ЕС требуют радикальные сдвиги в геополитической ситуации на европейском континенте и изменение геополитического статуса еврорегионов после масштабного расширения европейского сообщества. факторы

Ключевые слова: еврорегионы, еврорегиональное сотрудничество, трансграничное сотрудничество, (20)

Tsekhanovych Victor post-graduate student of the Department of economic theory, marketing and entrepreneurship Taras Shevchenko National University of Luhansk, Starobilsk

\section{EUROREGIONS: CHARACTERISTICS AND PRINCIPLES OF FUNCTIONING}

The article examines the principles of functioning and characteristics of euroregions. The forms of implementation of cross-border cooperation can vary from the establishment and development of mutually beneficial contacts between different entities and the conclusion of agreements on cross-border cooperation in certain areas to the creation of international territorial entities. International territorial entities that include border administrative units of 
neighboring states on the basis of concluded agreements are called euroregions. Euroregions are the highest form of cross-border cooperation, and their structures are the most comprehensive and effective form of education, within which various cooperation, coordination and corporate mechanisms are formed and operate. The development and implementation of fundamentally new approaches to the development of euroregions in Ukraine in the context of EU enlargement require radical changes in the geopolitical situation on the European continent and a change in the geopolitical status of euroregions after a large-scale expansion of the european community.

Summarizing the approaches to determining the essence of the euroregion the main functions of the latter are outlined: building strong cross-border links; addressing socio-economic, political and environmental issues problems of border territories; improving the standard of living of the population of border territories; information functions; establishment of communication channels; participation in the establishment of personnel and migration policy, as well as in improving legislation on cross-border cooperation; creating a positive image of a stable, responsible partner in the international arena, etc.

The expediency of an interactive level of international relations is noted, because at the present stage cross-border cooperation should be subject to a certain interactivity. In the context of this study, under interactivity refers to the exchange and addition of information and Human Resources Potential between by the parties of the euroregion, which should include the development of Joint Information, political, social-economic projects. The key point is the information process and the process of communication between population of the Euroregion.

Keywords euroregions, euroregional cooperation, cross-border cooperation, factors

Постановка проблеми у загальному вигляді. Аналіз багаторічного світового досвіду такогоо явища як транскордонне співробітництво свідчить, що воно є не лише інструментом поліпшення соціального та економічного розвитку прикордонних територій i навіть всієї країни. Найпоширенішою формою транскордонної співпраці $\epsilon$ співпраця в межах єврорегіонів, яка вважається ефективним інструментом вирішення економічних, соціальних, культурних та екологічних проблем та вирішення питань сталого розвитку в межах прикордоння. 3 огляду на це, вивчаючи та оцінюючи основні проблеми та перспективи транскордонного співробітництва: функціонування єврорегіонів, є важливою передумовою забезпечення загального розвитку України.

Аналіз останніх досліджень і публікацій. Малоефективність співробітництва регіонів, які відзначають більшість дослідників, слід також ув'язувати 3 відсутністю науково обгрунтованої методики оцінки ефективності єврорегіонального співробітництва, використання якої впливатиме на визначення проблемних аспектів та пріоритетні напрямки для його активізації.

Найбільш відомі теоретичні напрацювання щодо формування таких методик належать таким вітчизняним науковцям, як Мікула Н.А., Корольчук Л.В. Терещенко Т.В., Шилік Л.В., які в той же час підтверджують відсутність єдиного підходу до визначення ефективності єврорегіонального співробітництва.

Метою статти є виявлення особливостей функціонування єврорегіонів за участю України.

Виклад основного матеріалу дослідження. Вперше дефініція транскордонного співробітництва знайшла своє зако-нодавче та нормативне відображення у Європейській рамковій конвенції про транскордонне співробітництво між територіальними общинами. Відбулася ця подія у 1980 році, 21 травня у Мадриді, Іспанія [1].У конвенції закріплена доволі широка мета прикордонного співробітництва, що веде до посиленої регіональної інтеграції, яка обумовлюється територіальною близькістю і з'єднанням двох і більш просторових структур в конкретних районах $\mathrm{i}$ стабільністю контактів між ними, які обумовлюють взаємопроникнення економік, культур, традицій, інтелекту та ін. Саме такі структури вважаться основою створення сучасного 'врорегіону, в якому явно присутне одночасно виражене бажання районів різних держав різноспрямованого співробітництва: господарського, суспільного, культурного та іншого. Такі інтеграційні процеси, пов'язані зі створенням і існуванням спільних робочих органів і забезпеченням їх уніфікованого функціонування на рівні інституціонального транскордонного співробітництва вважаються найбільш ефективною формою європейського транскордонного співробітництва -'врорегіону (трансграничного регіону). Визначальною особливістю останнього є не лише те, що він забезпечує зміцнення добросусідських відносин між державами, а й сприяє інтеграції тієї чи іншої країни до європейських структур. 
Транскордонне співробітництво є важливим інструментом регіонального розвитку в умовах глобалізації та підвищення ролі регіонів на міжнародній арені. Такий вид співробітництва, починаючи з середини минулого століття, отримавособливе поширення у країнах Західної Європи, девже накопичено багаторічний досвід здійснення транскордонної співпраці, спрямованої на посилення та поглиблення добросусідськихвзаємовідносин між територіальними общинами або органами влади.

В Законі України «Про транскордонне співробітництво» № 2515-VIII від 04.09.2018p подається таке визначення транскордонного співробітництва: транскордонне співробітництво - спільні дії, спрямовані на встановлення і поглиблення економічних, соціальних, наукових, технологічних, екологічних, культурних і інших відносин між суб'єктами і учасниками таких відносин в Україні і відповідними суб'єктами і учасниками таких відносин із сусідніх держав у межах компетенції, визначеної їх національним законодавством, а єврорегіон як організаційна форма транскордонного співробітництва, що здійснюється відповідно до двосторонніх або багатосторонніх угод про транскордонне співробітництво.[2]

Для територіальних громад як суб'єктів транскордонного співробітництва важлива державна підтримка розвитку транскордонного співробітництва. Основними принципами державної підтримки розвитку транскордонного співробітництва $\epsilon$ [2]: об'єктивність, відкритість та економічна обгрунтованість відбору проектів (програм) транскордонного співробітництва для надання державної підтримки; концентрація фінансових ресурсів на пріоритетних та найбільш обгрунтованих проектах (програмах) з метою досягнення максимального ефекту їх реалізації; забезпечення умов для використання організаційних, фінансових, інституційних можливостей суб'єктів і учасників транскордонного співробітництва України у розробленні та здійсненні заходів щодо реалізації проектів (програм) транскордонного співробітництва; недопущення використання цільової державної підтримки для фінансування поточних потреб соціально-економічного розвитку регіонів.

Системоутворюючими складовими єврорегіону $є$ регіони, які входять до його складу. Вони мають як функції та завдання як в складі єврорегіону, так і зовнішні незалежні від нього, однак не позбавлені впливу на діяльність єврорегіону. Підсистемами та елементами єврорегіону є як структури за ознаками юридичних i фізичних осіб, так i функціональні щодо функцій фінансування, планування, проектування, організації, контролю, моніторингу тощо.

Згідно с цим роль єврорегіону обумовлюється здатністю до підвищення та ефективного використання існуючого потенціалу регіонів які до нього входять,та об'єднання потенційних можливостей для вирішення спільних проблем. на макрорівні, має поняття стійкості та безпеки процесу. Тому, коли мова йде про актуальність активізації єврорегіонів та позитивного динамічного розвитку, особливого наукового та практичного значення набуває, з одного боку, проблематика стійкого соціально-економічного та, в сучасних умовах, екологічного транскордонного розвитку, а 3 іншого, питання безпеки прикордонних територій, яка є станом об'єкта відносин з точки зору можливості забезпечення його виживання і розвитку в умовах внутрішніх і зовнішніх загроз, а також впливу непередбачуваних i важко прогнозованих факторів. Стійкість відображає міцність і надійність елементів і зв'язків усередині системи, здатність витримувати внутрішні і зовнішні навантаження і відновлювати нормальний стан системи після впливу зовнішніх або внутрішніх факторів.

Також виділяють фактори впливу на єврорегіони, які характеризують параметри макросередовища - економічні (вигідне геоекономічне розташування регіонів), соціальні (підвищення рівня людського розвитку, менталітет населення), політичні (діяльність уряду та наявності законодавчих та правових актів щодо транскордонного співробітництва). Завдяки економічним факторам існують потенційні можливості розвитку транскордонного співробітництва та кооперації, зокрема із суміжними регіонами сусідніх держав, соціальні відповідно визначають розвиток трудових ресурсів та рівня життя мешканців, а на основі політичних факторів здійснюється поступова трансформація національних комплексів у просторовий інтернаціональний комплекс. Зокрема це має відношення до євроінтеграційних прагнень України, а саме, через інтеграцію регіонів, у економічні структури країн $Є \mathrm{C}$.

Важливою особливістю територій у складі будь-якого еврорегіону, $є$ наявність загальних проблем транскордонного характеру. Задля вирішення їх необхідне об'єднання зусиль 
територіальних громад або органів влади по обидва боки кордону. Як правило, до таких проблем відносять екологічні та природоохоронні, розвиток прикордонної інфраструктури, транспорту та комунікацій, раціональне використання трудових ресурсів, забезпечення умов для розвитку етнічних меншин. Периферійність, існуваннязагальних соціально-економічних, демографічних, етнокультурних та екологічних проблем потребує об'єднання зусиль територіальнихгромад та місцевих органів влади держав-сусідів.

До загальних інтересів членів єврорегіонів найчастіше відносять еколого-економічні та природоохоронні, розвиток виробничо-господарської діяльності, розвиток прикордонної інфраструктури,транспорту і комунікацій, раціональне використання природногокапіталу і трудових ресурсів. Особливо важливим тут $\epsilon$ усвідомлення існування спільних інтересів на рівні прикордонних територіальних громад, місцевої бізнес-спільноти та регіональної влади. Типовими $€$ спільні торговельно-економічні інтереси, а також у сфері загального розвитку туристичної діяльності, наданні взаємних послуг через державний кордон, створенні мережіспівробітництва у сферах науки, освіти та культури. Універсальна сфера спільних інтересів для членів будь-якого єврорегіону є визначення загальної стратегії просторового розвитку [3].

За таких умов, доцільно звернути увагу на фактори, що впливають на стійкий та безпечний соціально-економічний розвиток єврорегіонів (табл. 1) [4].

Фактори впливу на стійкий та безпечний соціально-економічний розвиток єврорегіонів

\begin{tabular}{|c|c|}
\hline $\begin{array}{c}\text { Групи } \\
\text { факторів }\end{array}$ & Фактори впливу \\
\hline Політичні & $\begin{array}{l}\text {-рівень розвитку міждержавних відносин між суміжними країнами; наявність територіальних } \\
\text { спорів та військових конфліктів у прикордонних зонах; } \\
\text {-наявність етнічних і релігіозних конфліктів; розбіжності та проблеми уніфікація політичних } \\
\text { систем суміжних країн. }\end{array}$ \\
\hline Економічні & $\begin{array}{l}\text {-щільність населення (заселеність, ступінь подвоєності території), склад населення, рівень } \\
\text { життя населення ті інші соціальні умови (освіта, медичне забезпечення, рівень безробіття); } \\
\text {-рівень економічного розвитку та галузева структура виробничих сил прикордонних } \\
\text { територій; } \\
\text {-наявність виробничо-господарської спеціалізації; інвестиційний клімат та ресурси } \\
\text { прикордонних територій і суміжних держав; близькість галузевих структур і можливість } \\
\text { спільного використання природних, трудових, науково-технічних ресурсів; наявність } \\
\text { інфраструктурних зв’язків між підприємствами суміжних територій; } \\
\text {-наявність проектів транскордонного співробітництва; торговельно-комерційний потенціал; } \\
\text { рівень інформаційного забезпечення. }\end{array}$ \\
\hline Екологічні & $\begin{array}{l}\text { екологічна ситуація в прикордонному регіоні: ступінь впливу рівня розвитку виробництв на } \\
\text { екологічний стан регіону, а також існування потенційної загрози екологічних чи то } \\
\text { техногенних катастроф і можливості їх спільного запобігання, ступінь дотримання } \\
\text { міжнародних норм і правил у сфері охорони навколишнього середовища. }\end{array}$ \\
\hline Інноваційні & $\begin{array}{l}\text {-ступінь розвитку науково-технологічної сфери прикордонного регіону (кількість } \\
\text { інноваційних виробництв, науково-дослідницьких об’єктів, впроваджених наукових та } \\
\text { науково-технічних робіт, поданих та отриманих заявок на видачу охоронних документів, } \\
\text { обсяг реалізованої інноваційної продукції, створення і використання передових технологій } \\
\text { тощо); } \\
\text {-інноваційний потенціал єврорегіону; } \\
\text {-участь у міжнародних наукових проектах, грантових програмах. }\end{array}$ \\
\hline $\begin{array}{l}\text { Обумовлені } \\
\text { кордоном }\end{array}$ & $\begin{array}{l}\text {-периферійність і суміжна прикордонність регіону; ступінь освоєння єврорегіону; } \\
\text {-рівень розвитку прикордонної інфраструктури; міграційні процеси (у т.ч. нелегальна } \\
\text { міграція); } \\
\text {-рівень трансграничної злочинності, контрабанда. }\end{array}$ \\
\hline Інституційні & 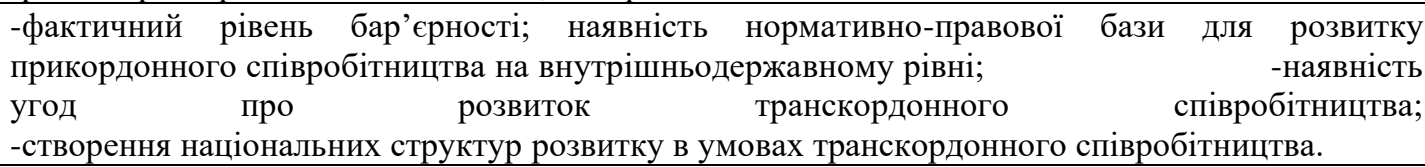 \\
\hline $\begin{array}{l}\text { Природно- } \\
\text { географічні }\end{array}$ & $\begin{array}{l}\text {-наявність і протяжність кордону, його ландшафтна характеристика; } \\
\text {-природно-кліматичні умови прикордонної території; наявність придатних для використання }\end{array}$ \\
\hline
\end{tabular}




\begin{tabular}{|l|l|}
\hline & земель с/г призначення; наявність і ступінь розробки природних ресурсів. \\
\hline Соціально- & -етнічна схожість населення; \\
культурні & - розбіжність державних рубежів з етнокультурними; наявність чи відсутність титульної нації \\
& на прикордонній території (поліетнічність); \\
& -конфесійні бар'єри; \\
& -наявність пам'яток культури і рекреаційних ресурсів; \\
& -схожість чи відмінності традицій та звичаїв. \\
\hline
\end{tabular}

3 обраного списку груп неможливо вибрати найважливіше або найвпливовіше, оскільки на інтенсивність єврорегіонів, як правило, впливає певний баланс багатьох з цих факторів, і вирішальну роль відіграє не фактор, а їх загальна вага. Залежно від ситуації в конкретній місцевості, роль будуть грати більш-менш конкретні фактори.. Особливу увагу слід приділити групі факторів інновацій так як нововведення, в сучасних умовах глобалізації транскордонного розвитку, його показників та динаміки в країні потенціал - це рушійна сила багатьох рішень у галузі міжнародного співробітництва та глобальної співпраці.

Практично у всіх статутах єврорегіонів $є$ ці фактори розвитку і допомоги територіям входять в дані утворення. Наприклад в єврорегіоні "Нижній Дунай" діють програми із захисту навколишнього середовища басейну Нижнього Дунаю, Пруту, Сірету і Дністра, дельти Дунаю, Придунайських озер, розробка спільних програм зі збереження рибних ресурсів Дунаю та Дністра, розробка та виконання спільних заходів щодо створення нових та розширення діючих природних ландшафтних заповідників, а також досягнення гармонічного, збалансованого розвитку економічної діяльності в регіоні

Можна навести приклад ще одного Єврорегіону - «Буг», до складу якого входять прикордонні регіони України, Польщі та Білорусі. Єврорегіон був створений у вересні 1995 року. Через його територію проходять важливі комунікаційні шляхи, які з'єднують країни Західної Європи 3 Україною та Білорусією. Основними цілями створення єврорегіону є розвиток комунікацій і зв'язку, вільний рух по єврорегіону товарівкапіталу, робочої сили, охорона довкілля і співробітництва в галузі екології.[5]

Як ми бачимо з прикладів цих двох єврорегіонів, які знаходяться на південному заході України цілі у них практично однакові.

Лідерами 3 повноти відображення положень документів національного рівня щодо транскордонного співробітництва у стратегіях регіонального розвитку є Львівська та Вінницька області. Незадовільний рівень продемонстрували Чернігівська, Київська та Рівненська області, тобто ті регіони, що вперше включені до програм транскордонного та територіального співробітництва. Загалом, чим більший досвід участі у програмах транскордонного співробітництва має регіон, тим більше уваги в стратегії приділяється питанням розвитку транскордонного співробітництва. Відповідно і вищим є ступінь відображення положень документів національного рівня. Експерти також вважають, що використання потенціалу програм територіального та транскордонного співробітництва СС для розвитку єврорегіонів, що великою мірою залежить від активності представників місцевої влади улобіюванні інтересів регіонів під час узгодженняцих програм. Жодна 3 досліджених областей, за виключенням Львівської, не має конкретизованих механізмів фінансування програм (проектів) за рахунок коштів програм транскордонного співробітництва. Така ситуація 3 фінансуванням програм транскордонного співробітництва 3 питань фандрайзингу, менеджменту коштів у межах бюджету транскордонних проектів, пошуку партнерів та диверсифікації джерел іх фінансування.[6]

До спільних інтересів членів єврорегіонів найчастіше відносять еколого-економічні та природоохоронні, розвиток виробничо-господарської діяльності, розвиток прикордонної інфраструктури,транспорту і комунікацій, раціональне використання природногокапіталу і трудових ресурсів. Особливо важливим тут $\epsilon$ усвідомлення існування спільних інтересів на рівні прикордонних територіальних громад, місцевої бізнес-спільноти та регіональної влада. Типовими $€$ спільні торговельно-економічні інтереси, а також у сфері загального розвитку туристичної діяльності, наданні взаємних послуг через державний кордон, створенні мережі співробітництва у сферах науки, освіти та культури.

Існуючі інституційні, правові та організаційні моделі побудови єврорегіонів, які давно апробовані на решті території Свропи показують, що залучення певної території до діяльності в 
рамках єврорегіону, а також до процесів транскордонного співробітництва взагалі, є шансом для вирішення традиційних проблем соціально-економічного розвитку, налагодження співпраці 3 партнерами по інший бік кордону, залучення інвестицій та налагодження міжособистісних контактів між різними етнічними групами населення. [7]

Важливим для діяльності єврорегіону є формування дійових зв'язків між елементами системи, оскільки суб'єкти знаходяться у відмінній системі економічних, фінансових, правових, територіальних координат (в різних країнах). Необхідною умовою $є$ уявлення про головні та другорядні зв'язки, тимчасові або взагалі непотрібні. Для цього можливим підходом є побудова відповідних матриць, оскільки не лише єврорегіон $є$ складною системою, такими системами $є$ й усі елементи, що його формують. Процес вибору рішення щодо кращої альтернативи або варіанту розвитку представляє аналіз всіх факторів впливу на кінцеві результати, їх взаємодії між собою та із зовнішніми впливами.[8]

Як показано у SWOT аналізе (табл.2) єврорегіони України за головною функцією $є$ соціально-економічною системою в основі якої знаходиться вирішення через фінансово-економічні фактори питання життєдіяльності населення в даний період або на перспективу, безпосередньо або опосередковано через покращення демографічної, екологічної ситуації, для всього населення регіонів або певної його частини.

SWOT-анализ функціонування українських єврорегіонів (авторська розробка)

Таблиия 2

\begin{tabular}{|c|c|}
\hline Сильні сторони & Слабкі сторони \\
\hline \begin{tabular}{l}
\multicolumn{3}{c}{ - вигідне географічне положення та участь } \\
України в єврорегіональному співробітництві; \\
- ресурсний потенціал \\
- розвиток транспортних і логістичних мереж; \\
- значний науково-технічний потенціал та \\
інтелектуальний \\
- участь у програмах та проектах ЄС; \\
-взаємний інтерес учасників інноваційного \\
єврорегіонального співробітництва до інтеграції \\
зусиль;
\end{tabular} & $\begin{array}{l}\text { - відсутність посиленої уваги органів } \\
\text { влади до розвитку єврорегіонального } \\
\text { співробітництва; } \\
\text { - відсутність гармонізованої статистичної } \\
\text { бази для проведення моніторингу; } \\
\text { - невідповідність нормативно-правового } \\
\text { забезпечення країн, що входять до } \\
\text { єврорегіону; } \\
\text { - значні диспропорції в посторово- } \\
\text { економічному } \\
\text { - монопольні переваги великого бізнесу } \\
\text { перед } \\
\text {-незначні темпи зростання інноваційної } \\
\text { діяльності; } \\
\text { - -виробництво з високими витратами. }\end{array}$ \\
\hline Можливості & Загрози \\
\hline $\begin{array}{l}\text { - посилення зв'язків та обмін досвідом що } \\
\text { приведе до розвитку економіки країни; } \\
\text { - використання європейських грантів для } \\
\text { інноваційної діяльності; } \\
\text { розширення можливостей інвестиційного } \\
\text { забезпечення; } \\
\text { - поліпшення інвестиційного клімату; } \\
\text {-поліпшення інституційного середовища } \\
\text { інноваційної діяльності; } \\
\text { обслуговування додаткових груп споживачі } \\
\text { - можливості інноваційного розвитку; } \\
\text { - використання досвіду європейський країн у } \\
\text { сфері інноваційного розвитку; }\end{array}$ & 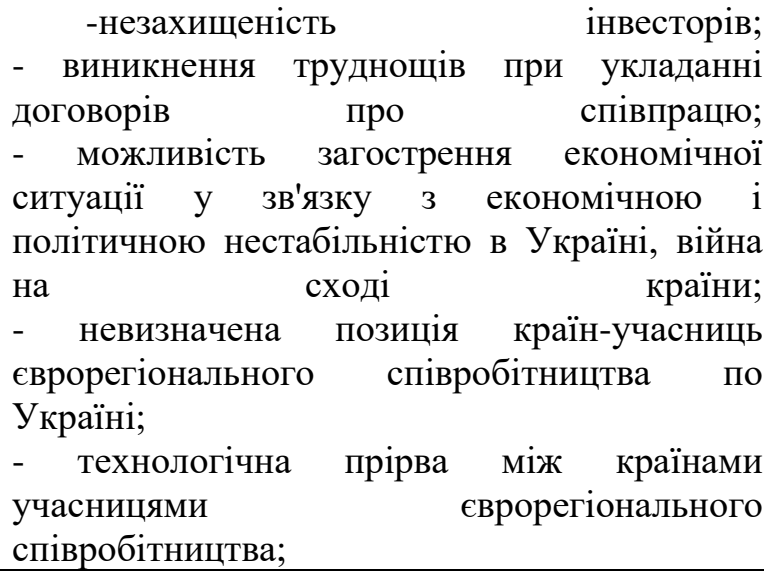 \\
\hline
\end{tabular}

Необхідною умовою ефективного функціонування єврорегіонів $є$ наявність чітко визначених спільних інтересів. Це можуть бути інтереси в торговельно-економічній сфері з урахуванням місця регіонів-партнерів у міжтериторіальному поділі праці, в галузі спільного розвитку туристичної 
діяльності, надання взаємних послуг через державний кордон, створення мережі співробітництва у сферах науки, освіти та культури. Ефективність діяльності єврорегіонів залежатиме від вибору науковообгрунтованих цілей; наявності достатніх інвестиційних ресурсів; раціональної організаційно-управлінської структури; вибору запотребуваних проектів та їх реалізації, формування дійових взаємовідносин між складовими частинами єврорегіону; розробки об'єктивних критеріїв оцінки та розподілу як ризиків, так і прибутків. Економічним завданням єврорегіону є реалізація функції перетворення інвестицій як головного фінансового ресурсу на вході в єврорегіон за рахунок ефективного управління, взаємодії підсистем, передбачення та врахування впливу різних факторів в отримання на виході прибутку в результаті проектного освоєння інвестицій.

Висновки. Проаналізувавши фактори впливу на діяльність єврорегіонів та виявивши всі загальні проблеми, ми можемо окреслити сфери, які потрібно подолати, та шляхи підвищення ефективності українськіх єврорегіонів. Крім того, вигідне географічне положення та характеристики нашої країни та неповна участь прикордонних територій у єврорегіонах створили передумову для подальшого розвитку транскордонного співробітництва та поглиблення міжнародних відносин. Ця ситуація вимагає впровадження всеосяжної національної політики, яка повинна підтримуватися відповідною законодавчою та фінансовою базою, а також зусиллями всіх зацікавлених сторін на державному, регіональному та місцевому рівнях.

Перспективи подальших досліджень. Необхідно провести поглиблені дослідження функцій та розвитку всієї складової єврорегіонів та, ефективного використання їх ресурсів та подолання історичних упереджень між населенням по обидва боки кордону, демократичного розвитку та потенціал для поліпшення управління.

\section{Джерела та література}

1 Європейська рамкова конвенція про транскордонне співробітництво між територіальними общинами або властями. URL: https://zakon.rada.gov.ua/laws/show/995_106 (дата звернення: 25.05.2021).

2. Про транскордонне співробітництво: Закон України № 2515-VIII от 04.09.2018 https://zakon.rada.gov.ua/laws/show/1861-15\#Text (дата звернення: 25.05.2021 81

3 Киш Є.Б Сврорегіон: теретико-методологічні засади дослідження_Регіональні студіï, № 10, 2017 cc.76-

4 Носач Л.Л., Величко К.Ю Активізація транскордонного співробітництва України в умовах євроінтеграції Молодій вчений № 5 (81) сс175-181

5 Долотіна К.В. Єврорегіони на территорії України: стан та проблеми розвитку. Вісник Східноукраіньского наииональногоуніверситету імені Володимира Даля 2013, №4(193) Ч.2. с194-198

6. О. Донцова Чому прикордонні області України втрачають фінансування з європейських програм https://gurt.org.ua/news/informator/45728/

7 Літвін Л. А. Функціонування єврорегіонів як складова реалізації національних інтересів Вісник Донецького національного університету імені Василя Стуса. Політичні науки. - 2019. - № 4. - м. Вінниця С. 63 68. - Режим доступу: http://nbuv.gov.ua/UJRN/vdonnupn_2019_4_12.

8. МікулаН.А., КалатЯ.Я. Єврорегіональне співробітництво в системі транскордонної співпраці. Соціально-економічні проблеми сучасного періоду України, Львів 2014. Вип. 4(108). С. 28-38.

\section{References}

1. Evropeyskoyi ramkovoyi konventsiyi pro transkordonne spivrobitni-tstvo mizh teritorialnimi obschinami abovlastyami [European Outline Convention on Transfrontier Co-operation between Territorial Communities or Authorities]. Available at: https://zakon.rada.gov.ua/laws/show/995_106 (accessed 25 May 2021) [in Ukrainian]..

2. Zakon Ukrainy Pro transkordonne spivrobitnytstvo [Law of Ukraine on Cross-Border Cooperation] № 2515VIII vid 04.09.2018 https://zakon.rada.gov.ua/laws/show/1861-15\#Text accessed 25 May 2021) [in Ukrainian]..

3. Kish E.B(2017) Yevrorehion: teretyko-metodolohichni zasady doslidzhennia[Euroregion: theoretical and methodological foundations of the study] Rehionalni studii, № 10 pp.76-81

4. Nosach L.L., Velychko K.Iu (2020) Aktyvizatsiia transkordonnoho spivrobitnytstva Ukrainy v umovakh yevrointehratsii [Activation of cross-border cooperation of Ukraine in the context of European integration] "Young Scientist” № 5 pp175-181 
5. Dolotina K.V.(2013) Yevrorehiony na terrytorii Ukrainy: stan ta problemy rozvytku.[ Euroregions on the territory of Ukraine: state and problems of development.] Visnyk Skhidnoukrainskoho natsyonalnohouniversytetu imeni Volodymyra Dalia №4 5 pp194-198

6 O. Dontsova(2018) Chomu prykordonni oblasti Ukrainy vtrachaiut finansuvannia z yevropeiskykh prohram https://gurt.org.ua/news/informator/45728/

7. Litvin L.A(2019) Funktsionuvannia yevrorehioniv yak skladova realizatsii natsionalnykh interesiv[Functioning of euroregions as a component of the implementation of national interests] Visnyk Donetskoho natsionalnoho universytetu imeni Vasylia Stusa. Seriia : Politychni nauky. - № 4. - pp 63-68. Available at http://nbuv.gov.ua/UJRN/vdonnupn_2019 4 _12.

8. MikulaN.A., KalatIa.Ia.(2014) Yevrorehionalne spivrobitnytstvo v systemi transkordonnoi spivpratsi. [Euroregional cooperation in the system of cross-border cooperation. Socio-economic problems of the modern period of Ukraine.] Sotsialno-ekonomichni problemy suchasnoho periodu Ukrainy. № 4. - pp 28-38.

Стаття надійшла до редакції 16.05.2021 р. 